\title{
Land use change, soil erosion and alluvial dynamic in the lower Doubs Valley over the 1st millenium AD (Neublans, Jura, France)
}

\author{
Boris Vannière $^{\mathrm{a} *}$, Gilles Bossuet ${ }^{\mathrm{a}}$, Anne-Véronique Walter-Simonnet ${ }^{\mathrm{a}}$, Emilie Gauthier ${ }^{\mathrm{a}}$, \\ Philippe Barral $^{\mathrm{a}}$, Christophe Petit ${ }^{\mathrm{b}}$, Martine Buatier ${ }^{\mathrm{c}}$, Alain Daubigney ${ }^{\mathrm{d}}$ \\ a Laboratoire de Chrono-Ecologie, UMR 6565 CNRS, UFR Sciences et Techniques, Université de Franche-Comté, 16 route de Gray, \\ 25030 Besançon cedex, France \\ ${ }^{\mathrm{b}}$ UMR 5594 CNRS, Université de Bourgogne, 6 Bd. Gabriel, 21000 Dijon, France \\ ${ }^{\mathrm{c}}$ Laboratoire de Géo-Sciences, UFR Sciences et Techniques, Université de Franche-Comté, 16 route de Gray, 25030 Besançon cedex, France \\ ${ }^{\mathrm{d}}$ Laboratoire de Chrono-Ecologie, UMR 6565 CNRS, UFR Sciences et Techniques, Université de Franche-Comté, 16 route de Gray, \\ 25030 Besançon cedex, France
}

Received 29 April 2002; received in revised form 23 December 2002; accepted 27 January 2003

\begin{abstract}
Geochemical and particle size analyses, surface scanning magnetic susceptibility, microscopic charcoal counting and pollen analysis, have been carried out on two cores from the lower Doubs valley in order to reconstruct the land use history. The interpretation of anthropogenic pollen indicators and micro-charcoal deposits is discussed in relation to the lithological variation of sedimentary accumulation and evolution of the settlement. The environmental changes which occurred during the 1st and the 6th century AD reflect the impact of human activities on the landscape in the immediate surroundings of the site. Multiproxy indicators indicate that soil erosion as a consequence of agricultural activities including fire practices. A reactivation of hydrologic flow of the river recorded in the sedimentary sequences attests to a larger environmental perturbation between 1st-3rd and 7th-8th century AD. (C)
\end{abstract}

Keywords: palaeogeography; erosion; fire; sedimentology; palynology; 1st millenium AD; France

\section{Introduction}

Soil-forming environments and erosion processes is a much debated question when studying the relationship between human impact and environmental change $[1,20]$. The impact of human activities (farming, agropastoral burning) on mechanical erosion is well established $[28,32,46,61,62]$. Other parameters, permanent or unvarying (size of watershed, lithology, relief), and variable factors (climate, hydrology, vegetation cover) have an effect on sediment yield and erosion rates $[40,42]$. Sediment yield also depends on dynamic agents such as gravity on slopes and running water [41]. For each geosystem, it is suitable to study its dynamic according to all parameters inducing erosion processes [1]. It is justified also to consider a joint impact of human and climate in the land use history

\footnotetext{
* Corresponding author

E-mail address: boris.vanniere@univ-fcomte.fr (B. Vannière).
}

$[4,6,23,31,49,62]$. Natural factors and human history are thus specific to each watershed. They appear as so many determining factors as there are possible reactions to mechanical erosion induced by climate changes and human occupation $[58,59]$.

For a few years now, archaeological survey has been carried out in the lower Doubs valley (Eastern France) to study the evolution of the settlement and to reconstruct the land-use history of the area from Antiquity until the Middle Ages [13]. The spatial extent of the archaeological remains and the chronology of occupation were precisely determined, but several interrogations remained concerning the environment of the settlement and the human impact on landscape. What are the characteristics of land management? Is there some relation between human occupation and river dynamic during the Antiquity? Which are the effects of clearing and cultivation on the sedimentary processes and soil formation? 


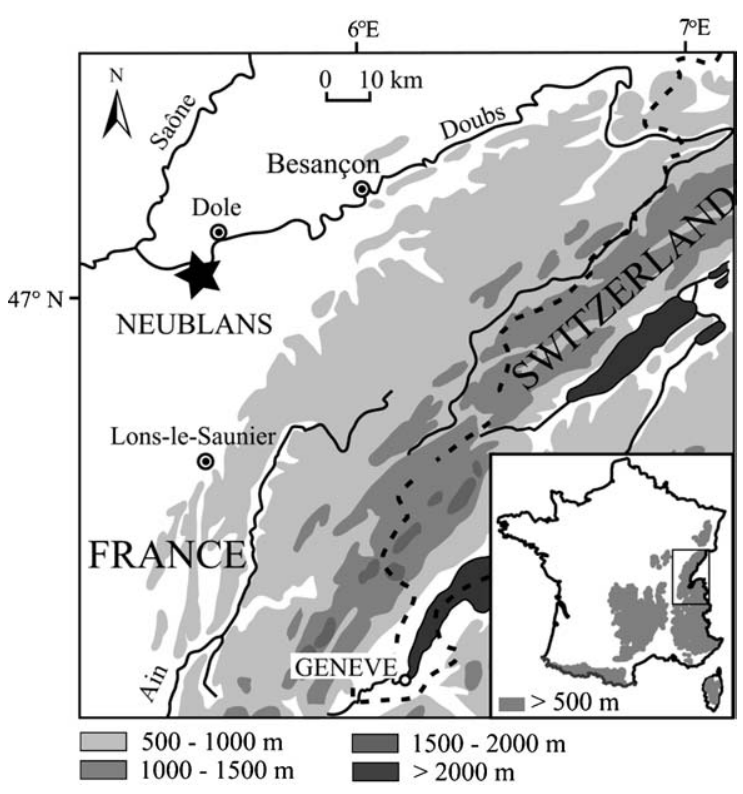

Fig. 1. Geographical situation of the investigation area of Neublans (Jura, France).

A multiproxy approach was adopted to examine a sedimentary sequence of the alluvial plain. The methods included sedimentological analyses (mineralogy, particle size, geochemistry, and surface scanning magnetic susceptibility), charcoal content and high resolution palynological analyses.

Thanks to these multiproxy indicators, it is now possible to propose an interdisciplinary synthesis of the influences of climate and human activities on the type and extent of vegetation and to determine how sedimentary dynamics have been indirectly affected by the environmental changes which occurred during those periods.

\section{Geographical and geological settings}

The investigation area of Neublans (Jura, France) lies at a mean altitude of $184 \mathrm{~m}$ asl and is located in the lower Doubs valley close to the Plateau Bressan, in the upper part of the confluence with the Saone river (Fig. 1). The Plateau Bressan is formed of sandy marl and Saint-Cosme formation (Fig. 2; [22]). Its surface is cut by numerous runnels. Colluviums fill the valley bottoms of the streams draining the surface water of the plateau. These brooks of ephemeral run-off contribute to the floods of the Doubs river. The southern valley side is largely covered by sandy clay colluviums derived from the Sand of Neublans formation underlying sandy marl. In the contact area with the flood plain, these sandy clay colluviums gradually overlap the Holocene alluvial deposits. The Sand of Neublans are dominated by quartz in contrast with the Quaternary alluvial deposits of
Doubs river which are characterised by carbonates $[47,48]$. The relief of the valley gives evidence of an ancient river course running at the bottom of the Plateau Bressan. At the present time, the Doubs river runs farther to the north in the alluvial plain.

An examination of historical sources allows us to identify the major part of the stream channels formed from the 17th century to the present day (Fig. 2; [53]). The fluvial morphology changes from the upper part to downstream-braided, anastomosing or meandering stream. Since the 18th century, the flow of the river has been successively embanked. Other features such as meander scroll, point bar and natural levee clearly separated from the modern shifting of the river, correspond to ancient drainage patterns of the Holocene period.

\section{Archaeological setting}

The Prehistoric period provides significant evidence of settlement spread over the entire window (Fig. 3A). Two fields of burial mounds dating back to the end of the Bronze Age and the beginning of the early Iron Age are both the mark of a lasting, socially structured settlement and of territorial division. From this period, several sites have provided materials corresponding to the late Bronze Age IIIb-Hallstatt C [14].

About ten sites of variable significance provide an illustration of the Iron Age, a time of increased economic integration, as observed in the study of artefacts. The transition from an indigenous farm to an actual agglomeration at the so called "Le Tertre" bears witness to the post-conquest dynamism of the second half of the 1st century BC [2].

For the Roman Period, a hundred sites have been identified (Fig. 3B). They all show an even spread of the settlements over the area, notably in the part of the plain liable to flooding [14]. The continuity of the settlement process has been observed in many cases, on different types of site. Various forms of settlement, complementary and socially structured, stand out. Two villages of significant size (30-40 ha) developed partly on the slope and partly in the plain [2]. Two smaller villages were found, along with a few establishments of the size of a hamlet. Many units, limited in size, are located along the Roman roads or in the surroundings of the "grouped" settlements. The impression of a scattered and heterogeneous settlement as well as the coexistence of a densely populated zone in the west and a sparsely populated zone in the centre and south, all stand out.

For this period, two great networks of land division as well as the framework of a third smaller one have 


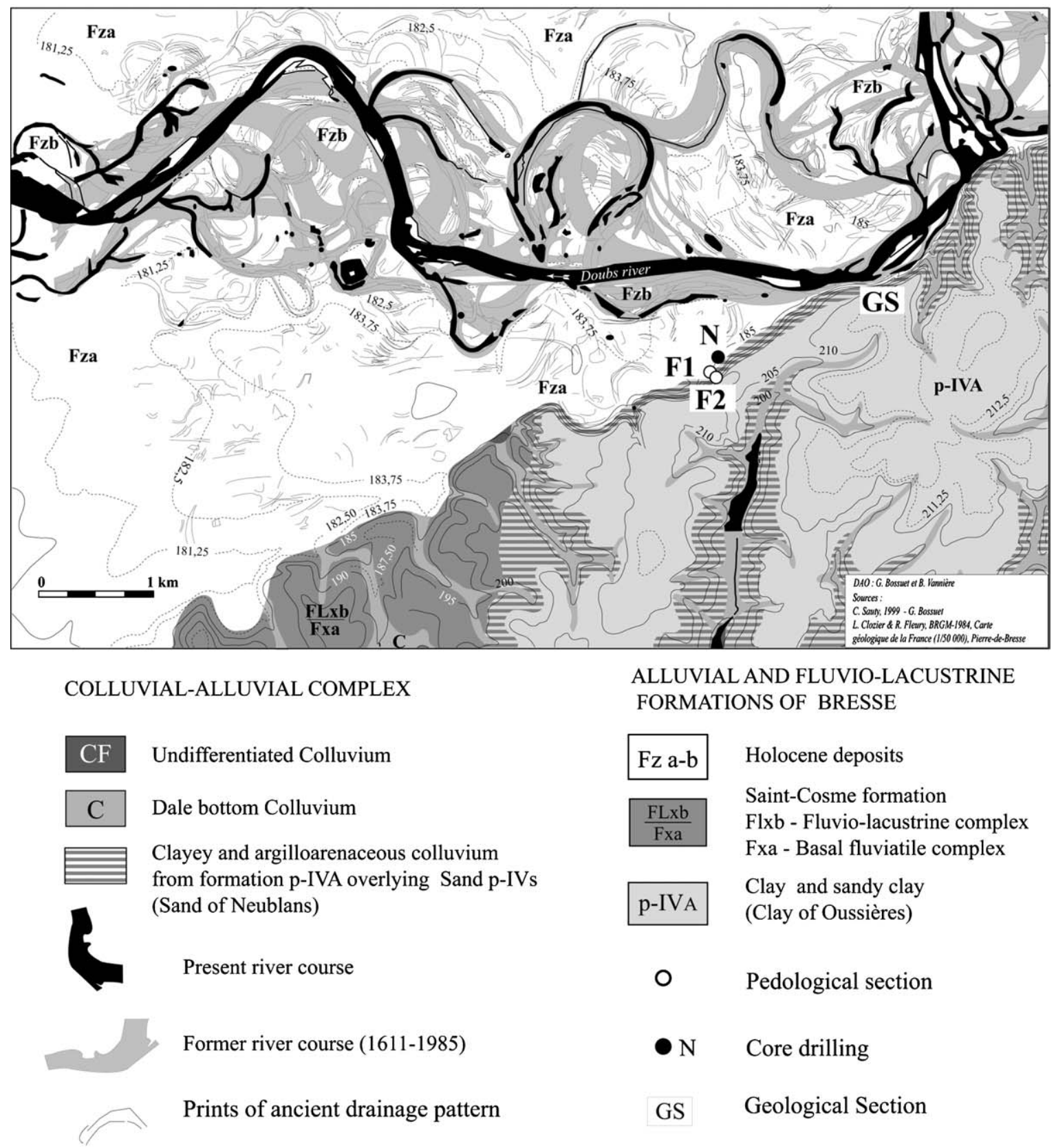

Fig. 2. Geological map of the investigation area in the lower Doubs Valley. Location of the sequences studied: geological section (GS), pedological section (F1 and F2) and core drilling (N).

been identified. The association of several significant Roman roads, the presence of fords and many access roads, all highlight the important role of crossroads in this area.

Archaeological [14], palynological [25] and sedimentological $[62,63]$ evidence consistently indicate that the farming activity must have reached its peak in the 2nd and 3rd century $\mathrm{AD}$, and then declined during the late Roman Empire (Fig. 3C). As shown by the development of vineyards during the 1st century AD [24], the land was farmed in an innovative and dynamic manner, at the beginning of the Roman Empire. The late Roman Empire period is best known for the continuity of some of its settlements, economically attractive during Antiquity. The patterns of settlement changed, probably due to the rise of ground water in certain areas [2].

As for the Middle Ages (Fig. 3D), some fifty potential sites have been identified. As early as the Merovingian and Carolingian times, a new way of structuring space developed. Small units of settlement gathered around villages, which thus became poles in the land organisation. Both the concentration of settlements and their 

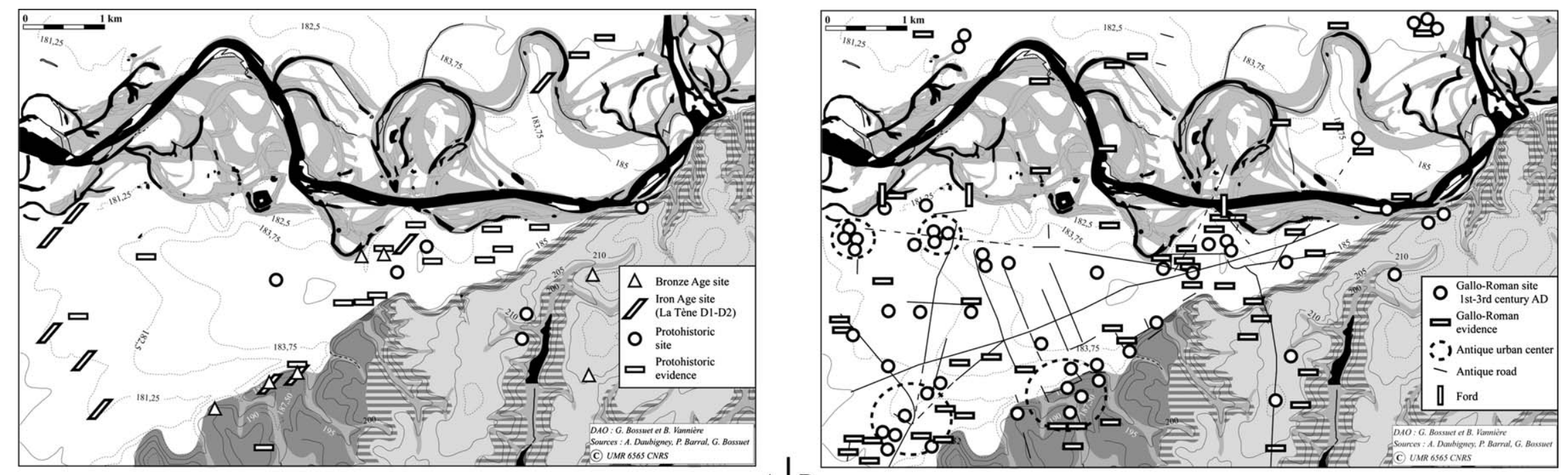
\begin{tabular}{l|l}
$\mathrm{A}$ & $\mathrm{B}$ \\
\hline $\mathrm{C}$ & $\mathrm{D}$
\end{tabular}
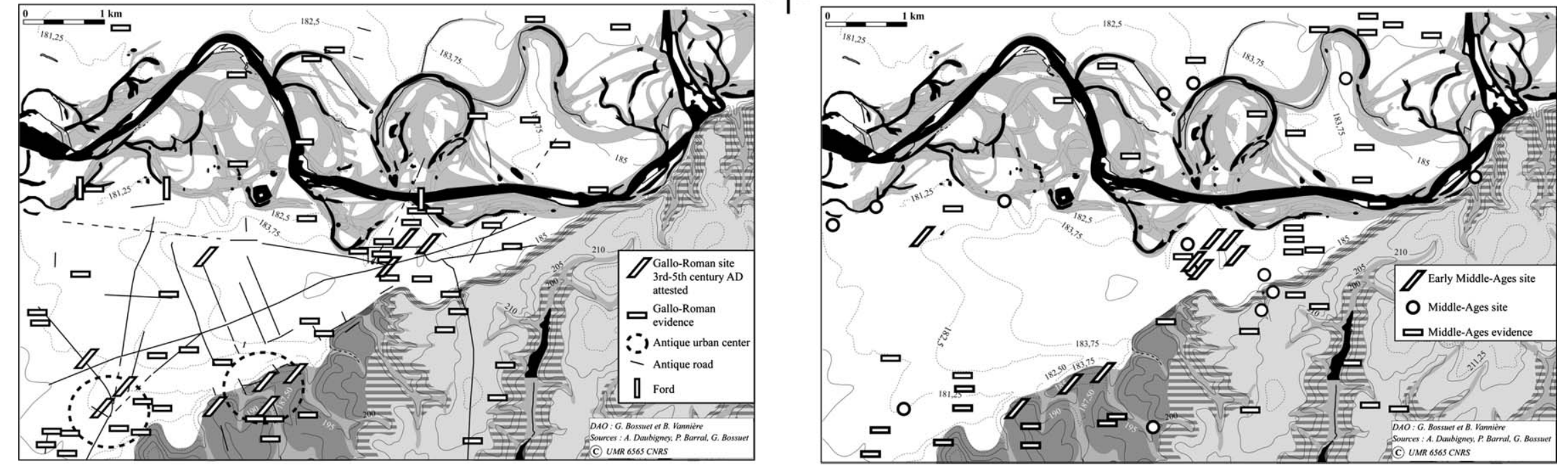

Fig. 3. Successive occupations in the lower Doubs valley as revealed by archaeological prospection. Protohistoric period (A), Early Roman Empire (B), Lower Roman Empire (C) and Middle Ages period (D). 


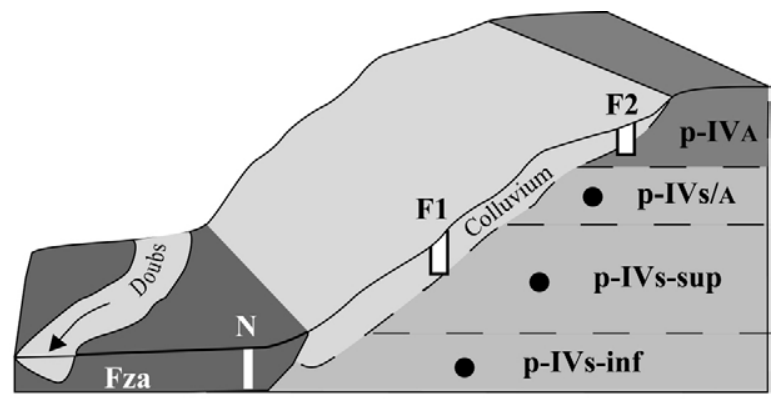

F.1

- Samples
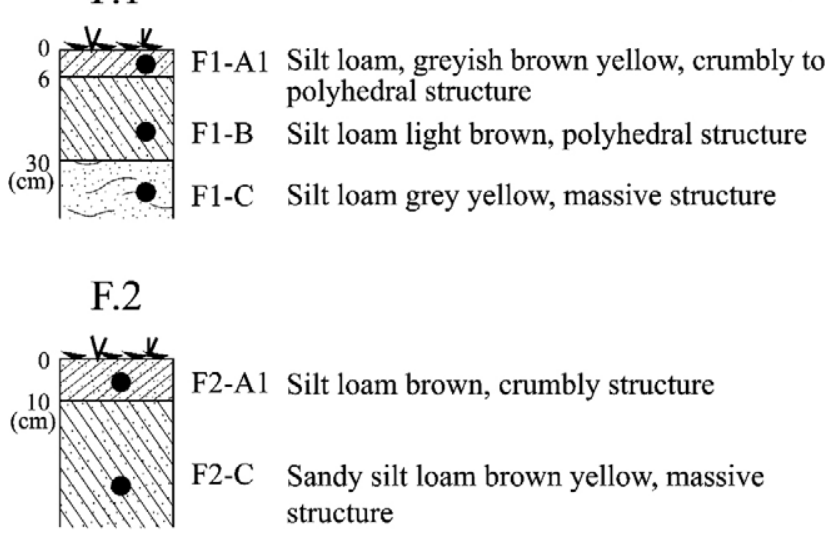

Fig. 4. Schematic 3D geological representation of the valley side. Location of the sampling core from alluvial plain $(\mathrm{N})$, pedological sections from the valley side (F1 and F2) and bedrock (geological formations: p-IVs-inf, p-IVs-sup and p-IVs/A).

spreading go hand in hand with the increasing part played by trade roads and crossroads, all of which can be observed in the emergence of numerous feudal mottes and dynamic demographic poles [14].

\section{Material and methods}

\subsection{Field sampling}

A sedimentary sequences $(\mathrm{N}$; from 90 to $520 \mathrm{~cm}$ depth), was taken in the flood plain with a Russian sampler, thus avoiding the compaction of sediments. The bore holes were located in a pool, at the bottom of the slope of the Plateau Bressan, probably a cutoff meander, filled up by flood deposits and peatyclayey sediments (Fig. 4). Pedological sections and geological formations of the Plateau Bressan were also sampled, in order to check the presence of sedimentary components derived from the erosion of the valley side in the previous alluvial-colluvial record (Fig. 4). In Sand of Neublans, three beds can be distinguished: a bottomset bed as a yellow classified sand (p-IVs-inf), an overlying stratum as a grey-iron rust sand (p-IVs-sup), more loamy than the previous bed and an upper bed as a grey-yellow loamy sand (p-IVs-A).

\subsection{Radiocarbon dating}

The chronology of the deposits is based on the pollen stratigraphy and three AMS radiocarbon dates respectively made for each sample on wood fragment, peat and terrestrial seed (Table 1).

The conversion from radiocarbon ages to calibrated calendar years was made with the program CALIB 4.1.2 $[55,56]$.

\subsection{Mineralogy}

Calcium carbonate content was determined by measuring the volume of $\mathrm{CO}_{2}$ evolved when a subsample

of known weight $(1 \mathrm{~g})$ of dry material was reacted with $10 \% \mathrm{HCl}$ in a calcimeter. Fifty-six sub-samples taken at $10 \mathrm{~cm}$ intervals were measured for the whole core.

Routine X-ray diffraction (XRD) analysis were made on bulk powdered samples and on individual fragments using a Philips PW1710 diffractometer. Samples were treated between $3^{\circ}$ and $65^{\circ} 2 \theta 40 \mathrm{kV} / 20 \mathrm{~mA}$, using $\mathrm{Cu}$ $\mathrm{K} a$ radiation, a $\mathrm{Ni}$ filter, and a scan speed of $1 \% \mathrm{~min}$. Quantitative XRD analysis is difficult in polyphased heterogeneous mixtures [19], and the relative abundance of minerals was estimated from the height of the main reflection and from comparisons with the reflections of other samples. The estimation of quartz and calcite content is expressed by the ratio Iquartz/Icalcite related to the intensity XRD peaks of these two minerals.

For XRD analysis of the clay fraction, a preparation of oriented aggregates of clays was then collected on a glass slide. The samples were sequentially air dried, glycolated and heated for $4 \mathrm{~h}$ at $490{ }^{\circ} \mathrm{C}$, for identification of interlayering of clays, i.e., the (001) basal reflection positions after each treatment. The XRD patterns were obtained between $2^{\circ}$ to $32^{\circ} 2 \theta$.

\subsection{Magnetic susceptibility}

Volume susceptibility was measured with portable MS2 magnetic susceptibility meter and a E1 surface scanning sensor (Bartington Instruments Ltd) at $2 \mathrm{~cm}$ intervals on the sediment surface of the whole cores. This sensor is designed to measure the susceptibility of split cores with fine resolution [16]. The sensitivity of the magnetic susceptibility meter used was $0.1 \times 10^{-8}$ SI allowing a high differentiating capacity for sedimentary characterisation [63].

\subsection{Particle size analyses}

Particle size analysis was achieved by using a coulter laser Micromultisizer LS 230 after sieving at $1 \mathrm{~mm}$. Forty-three sub-samples were taken at $10 \mathrm{~cm}$ intervals in the sedimentary core, and eight samples in the pedological sections and geological formations from the valley side (Fig. 4). 
Table 1

AMS radiocarbon dating of core $\mathrm{N}$.

\begin{tabular}{lllll}
\hline Depth & Age ${ }^{14} \mathrm{C}$ BP & Calibrated age $2 \sigma$ & Laboratory reference & Material \\
\hline $125 \mathrm{~cm}$ & $1257 \pm 40$ & cal AD [664 (725, 739, 772) 887] & Utc 9398 & Terrestrial seed \\
$270 \mathrm{~cm}$ & $1715 \pm 41$ & cal AD [238 (264, 272, 340) 422] & Utc 6997 & Peat \\
$445 \mathrm{~cm}$ & $1972 \pm 34$ & cal BC [44 (cal AD 28, 41, 49) cal AD 122] & Utc 6999 & Wood \\
\hline
\end{tabular}

In order to obtain detailed information on the grain size distribution sediment samples for granulometric analysis were treated according to the method described by Brun-Cottan [8] and Lesourd [35]. In that way, samples were characterised by the relative area of their particle size populations, and compared between them. The terminology used for description of main particle size class is given as clays: $0-2 \mu \mathrm{m}$, silt: $2-20 \mu \mathrm{m}$, coarse silt: $20-50 \mu \mathrm{m}$, fine sand: $50-200 \mu \mathrm{m}$, coarse sand: $200 \mu \mathrm{m}-2 \mathrm{~mm}$.

\subsection{Pollen analysis}

Pollen analysis was carried out on the core N. Samples were taken at $5 \mathrm{~cm}$ intervals between $90-520 \mathrm{~cm}$ $[24,25,63]$.

In this study, special attention was paid to the anthropogenic pollen indicators (API). The reliability of pollen evidence to emphasis human influence has been firmly established $[5,3,33]$. Pollen indicators of human impact are from different taxa and take into account the increase of pollen yielded by cultivated plants (mainly Cerealia, Vitis), crop-weeds, grass meadows and ruderals (Plantago lanceolata and major/ media, Artemisia, Rumex, Chenopodiaceae, Urticaceae, Polygonum aviculare type).

\subsection{Charcoal content}

The analysis of the fire-signal on core N1 was carried out on the basis of a microscopic observation in reflected light (LR) of micro-charcoal (size between 10 and $100 \mu \mathrm{m})$ present in the pollen-slides. Reflected light microscopy allows a better characterisation of the dark remains by surface observations and make it possible to separate micro-charcoals from opaque minerals and oxidised vegetal remains [62].

Two types of textures were differentiated in the counting of the charcoal particles: cellulose ligneous structure or rounded massive structure. Cellulose ligneous particles present a cellular porosity and a structure evocative of plant tissues. Their ratio length/width $>1.5$ is characteristic of charcoal particles $[10,11]$. The isotropous particles have a ratio length/width $\simeq 1$, they are often rounded and characterised by the absence of porosity. Their morphology is a result of a postdepositional fragmentation in soil before their sedimen- tation in the alluvial sequence record [62]. Thus, any fire signal is inherited from soil erosion. Inversely, elongated cellulose ligneous particles immediately deposited in the alluvial sequence record, appear as signatures of the fire events [62].

Results were expressed in quantity of particles per gram of sediment. However, calculating particle frequencies is more advisable for a valuable interpretation of the significance of peaks in charcoal content $[9,62]$. In our case, a means of estimating the charcoal particles influx was to calculate the ratio $\mathrm{C} / \mathrm{P}$ (charcoal/pollen) considering the fluctuations of total pollen concentration as an indicator of variation in sedimentation rate [57].

\section{Results}

\subsection{Mineralogy and magnetic susceptibility}

The mineralogy of the sediments is quite similar on the whole core (Table 2). The dominant minerals are quartz and calcite. Semi quantitative results indicate that feldspars and dolomite are present in very low quantities. Samples from geological formations present the same mineral composition. In the sedimentary core $\mathrm{N}$, in geological formations and soils, the dominant clayey minerals are illite, chlorite, kaolinite and smectite with mixed layer clay. The similarity of mineralogy characteristics between sediments from the alluvial plain and sediments from the valley side indicate the genetic origin of the deposits of core N. Only variations in carbonate and siliceous components, in organic matter and structure allow a zonation of phases in the sedimentary sequence (Fig. 5).

Five phases $\mathrm{A}$ to $\mathrm{E}$ and a sub-phase $\mathrm{B}^{\prime}-\mathrm{MS}$, were identified in reference to the magnetostratigraphy, sedimentogical description and mineralogical analysis (Fig. 5).

The basal sedimentary accumulation (phase A) corresponds to silty loam colluviums of massive and compact structure. The grey blue colour attests a reducing and hydromorphic depositional environment involving the formation of a gley. Carbonate content varies between 35 and $45 \%$. The evaluated ratio of quartz/calcite varies from 0.6 to 0.8 with a value of 1.3 at a depth of $430 \mathrm{~cm}$. Sandy and organic layers (radiocarbon dated) were observed. The values of magnetic susceptibility 
Table 2

Mineral composition of the sediments for core $\mathrm{N}$ (sample numbers refer to depth), for pedological sections F1 and F2 and for geological formations p-IVs-inf and p-IVs-sup.

\begin{tabular}{|c|c|c|c|c|c|c|c|c|}
\hline \multirow[t]{2}{*}{ Samples } & & \multicolumn{4}{|c|}{ Bulk rock } & \multicolumn{3}{|l|}{ Clay fraction } \\
\hline & & Quartz & Felspars & Calcite & Dolomite & Mica (Illite) & Chlorite + Kaolinite & Smectite $( \pm$ IS) \\
\hline \multirow[t]{4}{*}{ Pedological sections } & F1-A1 & $* * *$ & $*$ & & & $*$ & $*$ & - \\
\hline & $\mathrm{F} 1-\mathrm{C}$ & $* * *$ & $*$ & & & $*$ & $*$ & - \\
\hline & F2-A1 & $* * *$ & $*$ & & & $*$ & $*$ & - \\
\hline & $\mathrm{F} 2-\mathrm{C}$ & $* * *$ & * & & & $*$ & $*$ & - \\
\hline \multirow{2}{*}{ Geological sections } & pIVs-sup & $* * *$ & $*$ & $* *$ & $*$ & $*$ & $*$ & $*$ \\
\hline & pIVs-inf & $* * *$ & $*$ & $* *$ & $*$ & $*$ & $*$ & $*$ \\
\hline \multirow[t]{11}{*}{ Core drilling $\mathrm{N}$} & N 110 & $* * *$ & - & $* *$ & - & $*$ & $*$ & $*$ \\
\hline & N 150 & $* *$ & - & $* * *$ & - & $*$ & $*$ & $*$ \\
\hline & N 180 & $* * *$ & - & $* *$ & - & * & * & $*$ \\
\hline & N 240 & $* *$ & - & $* * *$ & - & * & * & $*$ \\
\hline & N 260 & $* * *$ & - & $* * *$ & - & $*$ & $*$ & $*$ \\
\hline & N 310 & $*$ & - & $* * *$ & & $*$ & $*$ & $*$ \\
\hline & N 390 & $*$ & - & $* * *$ & - & $*$ & $*$ & $*$ \\
\hline & N 410 & $* *$ & - & $* * *$ & - & $*$ & * & $*$ \\
\hline & N 430 & $* * *$ & - & $* *$ & - & $*$ & $*$ & $*$ \\
\hline & N 460 & $* *$ & - & $* * *$ & - & $*$ & $*$ & $*$ \\
\hline & N 500 & $*$ & - & $*$ & - & $*$ & $*$ & $*$ \\
\hline
\end{tabular}

Semi-quantitative results from XRD analyses are given as: ***: very abundant; **: abundant; *: present; -: detected.

vary from 60 to $250 \times 10^{-5}$ SI (mean value at $80 \times 10^{-5}$ SI). Over the general trend of magnetic susceptibility, the curve shows a series of peaks which are strongly marked for the core N2.

A second sedimentary unit (phase B) shows a coarser structure, well differentiated by brown colour and organic components of the matrix. The carbonate content, excluded organic layers at a depth of $270 \mathrm{~cm}$ and 350 $\mathrm{cm}$, is higher with a mean value between 55 and $65 \%$. The evaluated ratio of quartz/calcite is $<0.3$. Total pollen concentration shows variations of high amplitude correlated both to an organic matter enrichment of sediments and the development of peat facies (at a depth of $270 \mathrm{~cm}$ ). This phase shows a smooth profile of the magnetic susceptibility curve with low values (10 to $20 \times 10^{-5} \mathrm{SI}$ ) that correspond to a change in sedimentation sources (facies more loamy) with an increase of carbonate content involving a dilution of the magnetic signal [28]. In phase $\mathrm{B}^{\prime}$-MS, a small increase of magnetic susceptibility is recorded $\left(40 \times 10^{-5} \mathrm{SI}\right)$. Nodules of secondary carbonation and a small decrease of the organic component can be related to this evolution. These nodules result from the secondary precipitation of calcite after a sparing dissolution in soils [21]. A significant increase in the total pollen concentration is related to this evolution. At the end of this phase $\mathrm{B}$, the lower values of magnetic susceptibility ( 0 to $10 \times 10^{-5} \mathrm{SI}$ ) correspond to organic deposits.

The third sedimentary unit of grey yellow colour (phase C) shows a finer texture than the previous unit and an increase of magnetic susceptibility up to $60 \times 10^{-5}$ SI. The massive structure and the carbonate content between 35 and $40 \%$ appear similar to the basal sedimentary accumulation. The ratio of quartz/calcite is $>0.8$ and even $>1$ at a depth of $180 \mathrm{~cm}$. The organic matter is represented by scattered residues of plant cells of millimetre and centimetre sizes. These organic components correspond to the persistence of a hygrophile vegetation growth in the sedimentation area. Magnetic susceptibility and other proxies record a new change in sedimentary sources and erosive process.

The fourth sedimentary unit (phase D) is obviously similar to the third unit characterised by a decrease of carbonate content. The decrease of magnetic susceptibility closely coincides with a passage to organic facies (peat).

Phase E corresponds to a new increase in magnetic susceptibility and to a significant increase in the ratio of quartz/calcite.

\subsection{Grain size distribution}

Grain size distribution for samples of core $\mathrm{N}$ are somehow of plurimodal type (Fig. 6). The relative proportion of particle size class allows to define five sedimentary units (Fig. 7) similar with those displayed by mineralogy and magnetic susceptibility analyses (Fig. 5).

Basal accumulation (A), sedimentary units C and E, are characterised by a clayey fraction and a dominance of silt. The difference observed lies in the slight proportion of coarse sand. The sedimentary units B and D show abrupt increase of grain-size with regard to the other units (Table 3).

Particle size class characteristics of geological and pedological formations are also presented in Figs. 6 


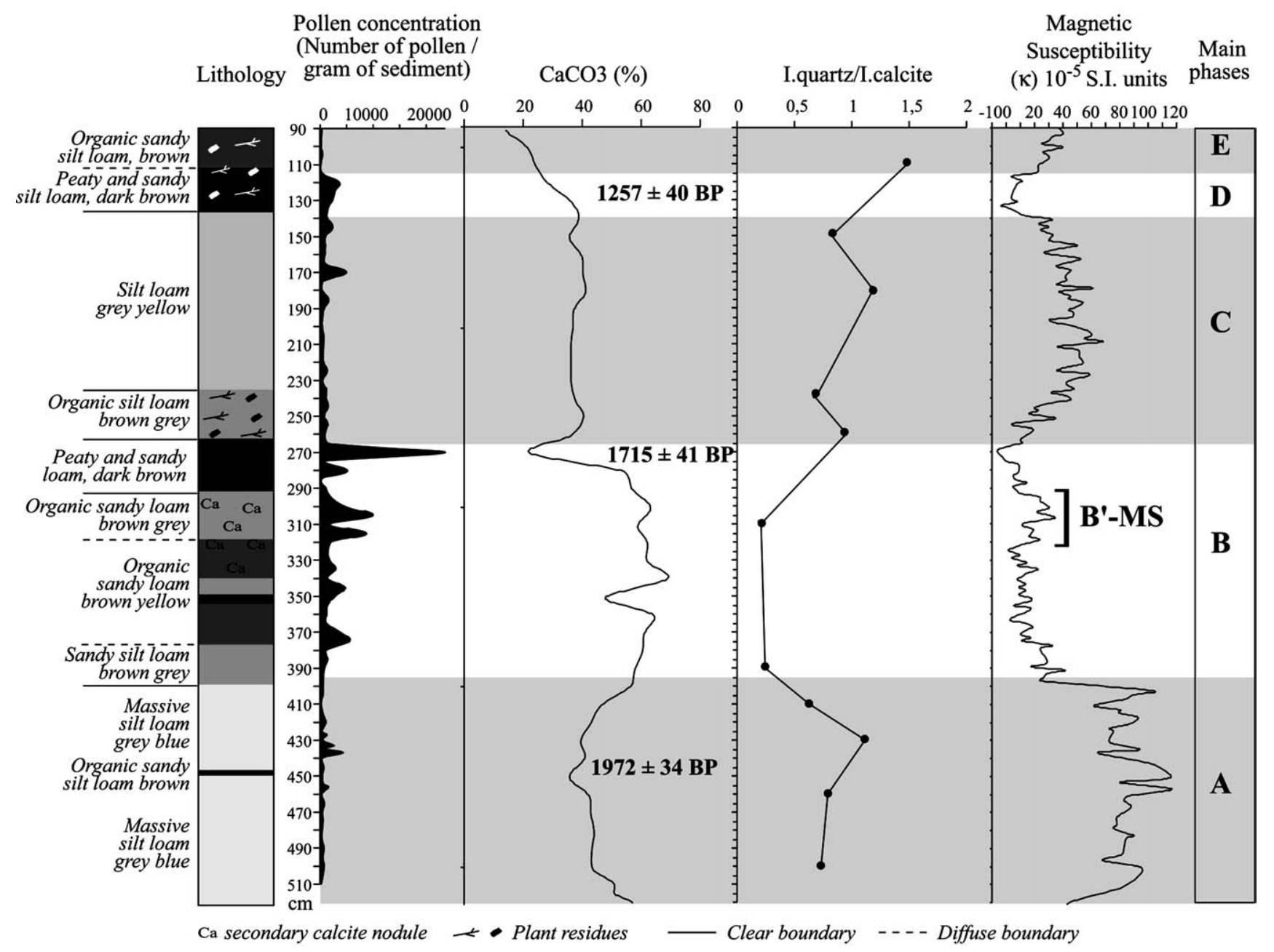

Fig. 5. Core $\mathrm{N}$ from Neublans (Jura, France). Lithology, pollen concentration, $\mathrm{CaCO}_{3}(\%)$ content, ratio of Intensity XRD peaks for quartz and calcite, and whole core volume susceptibility. Main phases of the stratigraphic evolution (A to E) and local phase $\mathrm{B}^{\prime}$-MS.

and 7. The sands (p-IVs-inf) of the bottomset bed are very well sorted (fraction $100-250 \mu \mathrm{m} \approx 70 \%$ ). The overlying stratum p-IVs-sup, is more finely textured (fraction $<5 \mu \mathrm{m} \approx 35 \%$ ). The upper bed ( $\mathrm{p}-\mathrm{IVs}-\mathrm{A}$ ) appears as a transitional stratum to sandy marl (p-IVA). The fine fraction is well represented, but fine sand assigns these sediments to the geological formation "Sand of Neublans".

Grain size distribution of soil samples are plurimodal; the dominant particle size classes are $<50 \mu \mathrm{m}$. For soil $\mathrm{F} 1$, there is no particle up to $100 \mu \mathrm{m}$ in size. Only deep F1-C horizon shows a grain size class up to $200 \mu \mathrm{m}$. For pit F2, sands are represented in the fraction up to $200 \mu \mathrm{m}$. The F2-A1 horizon is a more finely textured, with a smaller content of sand.

The particle size class up to $1000 \mu \mathrm{m}$ appears as typical from peat layers and organic matter enrichment of sediments. The significant proportion of the 100-150, 150-200 and 200-250 $\mu \mathrm{m}$ particle size classes in sedimentary phases $\mathrm{B}$ and $\mathrm{D}$ of the filling reveals an erosion of the formation p-IVs-inf. However, this fraction is of no great significance in the size grading of sediments. The occurrence of the grain size class $600-700 \mu \mathrm{m}$ in the sediments filling attests to an erosion of the deep layers of soils on the Plateau (represented by horizon F2-C in soil section F2). This erosion process is again recorded by the particle size class $250-400 \mu \mathrm{m}$ which is typical of the $\mathrm{p}$-IVs/A facies.

\subsection{Vegetation and fire history}

Five main phases (A, B, C, D and E) can be clearly identified in charcoal curves and in the evolution of the API (Fig. 8 \& Fig. 9). They are similar to these defined in the previous sedimentological analyses.

Phase A, corresponds to a period of intense agricultural development centred over the first two centuries AD. High rates of Poaceae and pollen indicators of pasture would indicate an open landscape. Pollen of arable land (e.g. Cerealia, Secale, Cannabis) show high 


\section{Core $\mathrm{N}$}
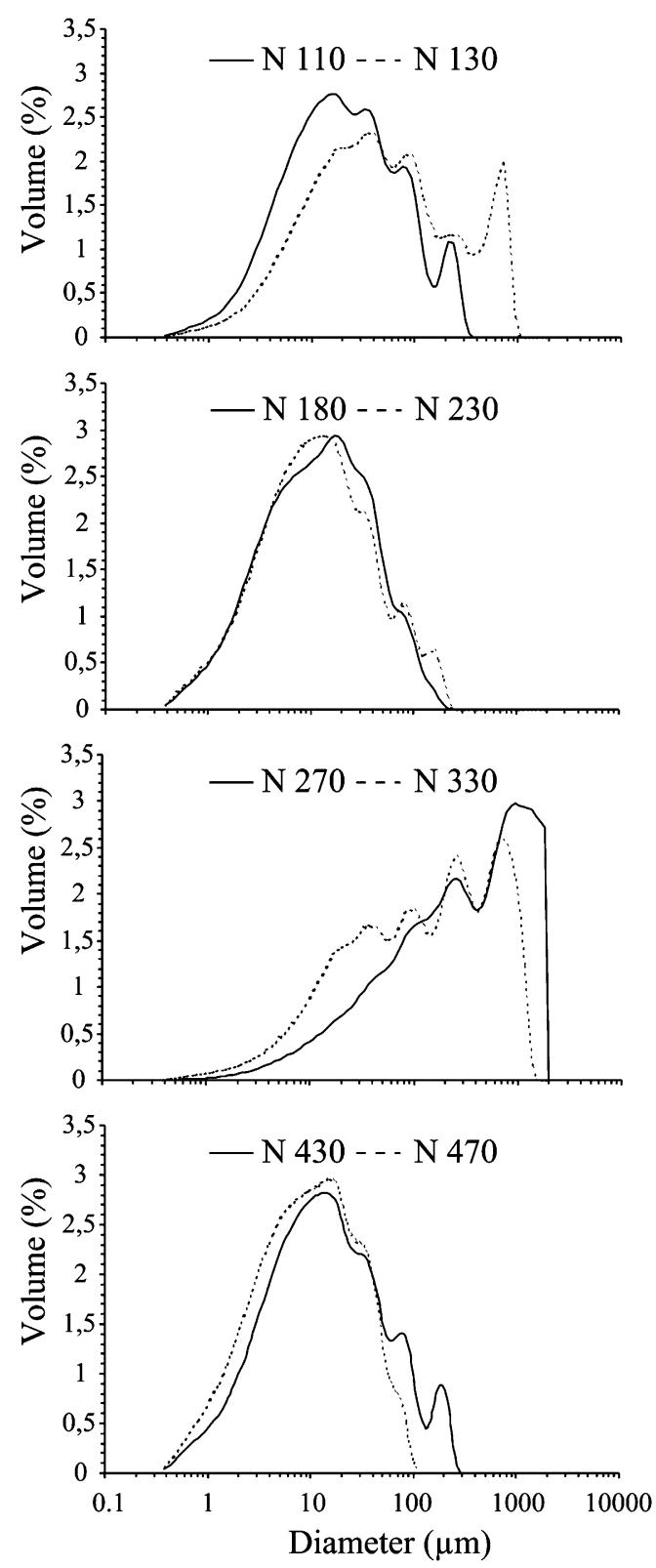

Pedological and geological sections
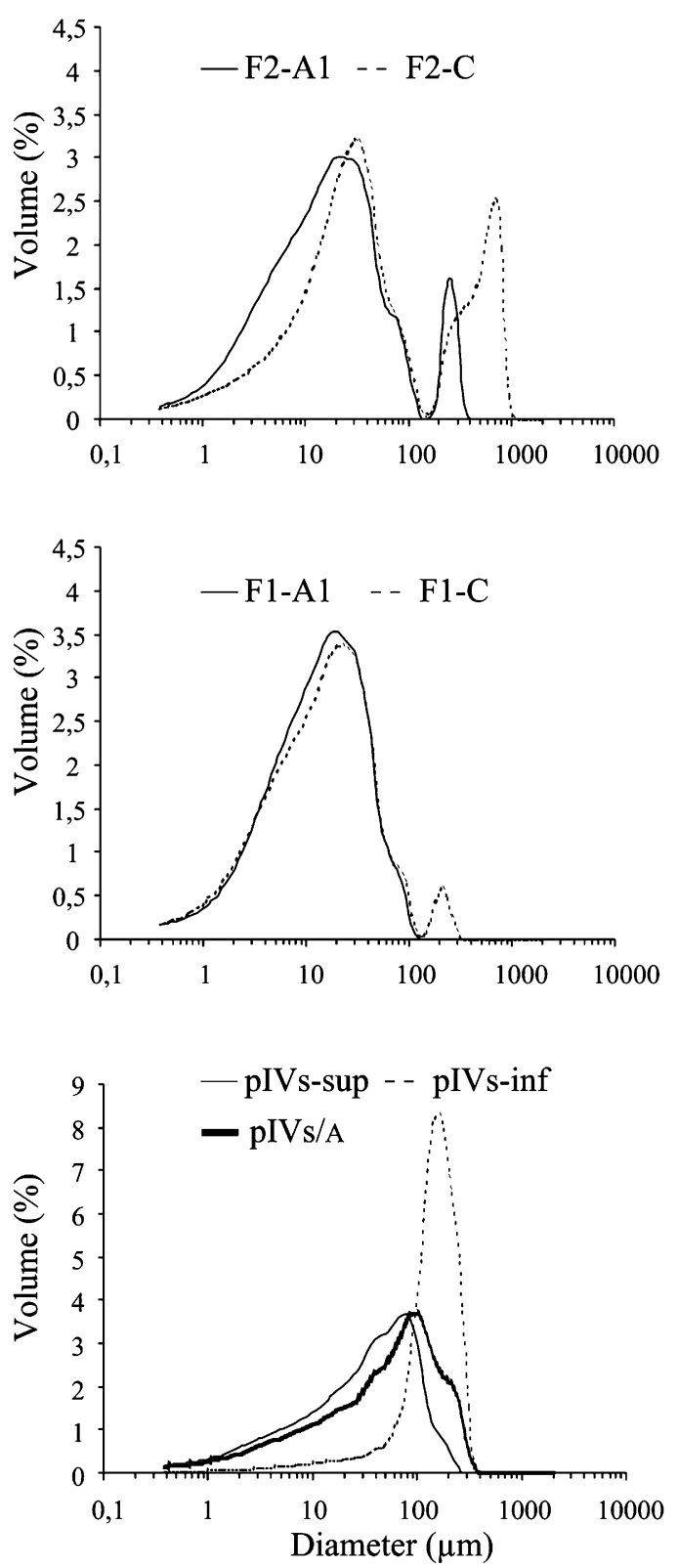

Fig. 6. Typical curves of particle size analysis in volume (\%) for several samples from the core $\mathrm{N}$ (sample number refer to depth), pedological sections $\mathrm{F} 1$ and F2 and geological formations p-IVs-inf, p-IVs-sup and p-IVs/A.

values reflecting the cultivation of cereals and hemp in the surroundings of the site. Vitis pollen accounts for 1 to $4 \%$ indicate a probable cultivation of vine on the valley side as far back as the 1st century AD ([cal BC 44, cal AD 122]; Table 1; [24]). Study of the modern pollen rain of Vitis shows clearly its low pollination [30]. The sheet erosion of the valley side and the runoff of the fine sediments could explain the transport and the deposition of Vitis pollen in the sedimentary accumulation of the flood plain. The fluctuations of human impact indicators and charcoal content appear synchronous, suggesting a use of fire for cultivation. The forest cover is represented by Quercus, Carpinus and Fagus pollen. Alnus pollen probably represents the riparian woodland. A low decrease of API is recorded at the end of the phase A. The high rates of $T$. angustifolia, might be considered a local pollen rain.

Evidence of a decrease in agricultural activity is gathered in phase B. It begins approximately around the second half of the 2nd century AD ([238 $(264,272,340)$ 422] cal AD; Table 1). The pollen spectra show a sharp decrease in API and lower frequencies of microscopic charcoal particles, except sub-phase $\mathrm{B}^{\prime}$-PCh where an occurrence of massive particles is closely connected to an 
Distribution area (\%) of each particle size class $(\mu \mathrm{m})$

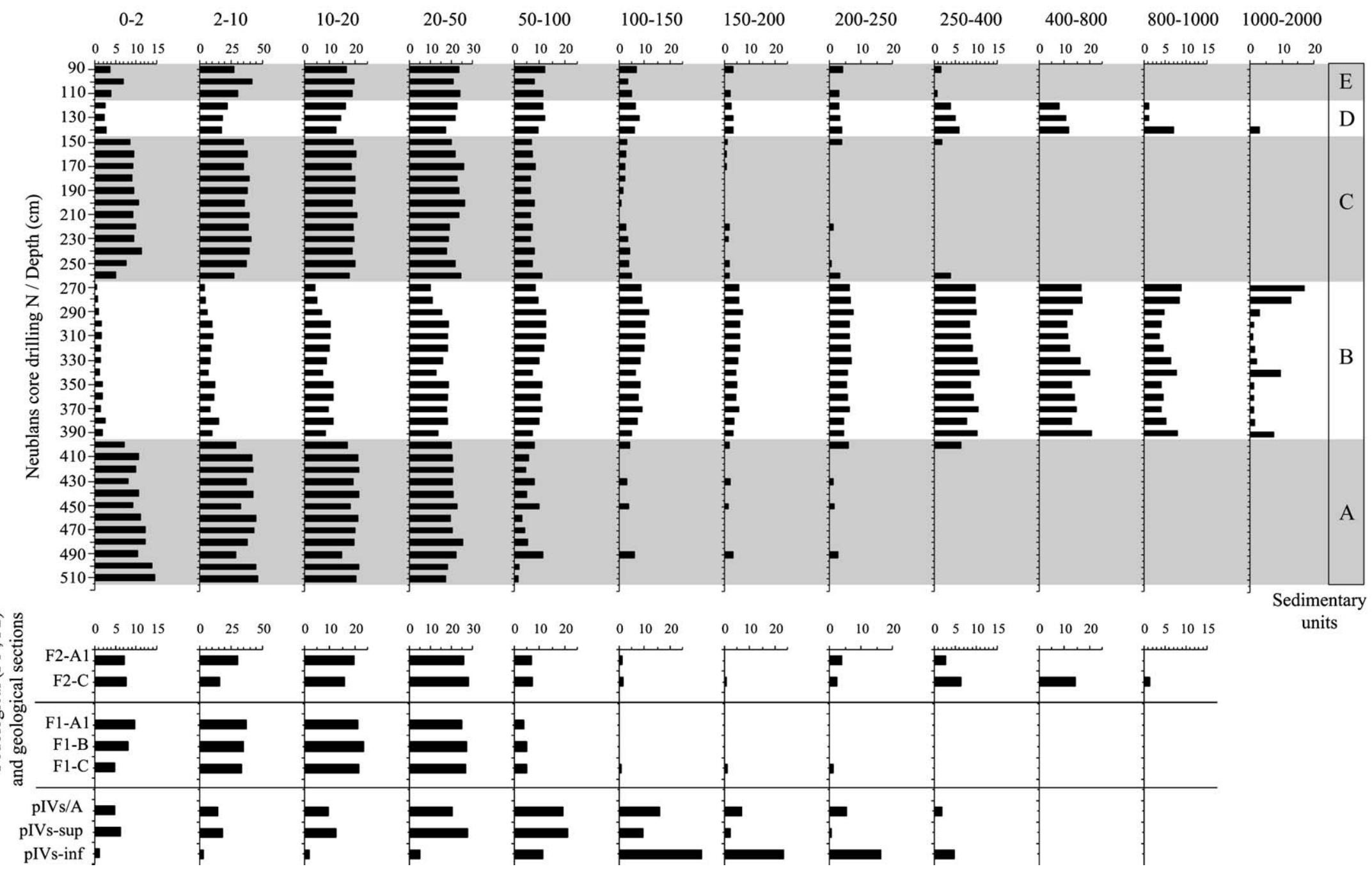

Fig. 7. Size grading for the whole core N, for pedological sections F1 and F2 and for geological formations p-IVs-inf, p-IVs-sup and p-IVs/A. 
Table 3

Description of the sedimentary units from the whole core $\mathrm{N}$

\begin{tabular}{lll}
\hline $\begin{array}{l}\text { Sedimentary } \\
\text { unit }\end{array}$ & General characteristics & Punctual observations \\
\hline A & Clay: 7-14\% Silt: $60-70 \%$ & $\begin{array}{l}\text { Some layers } 5 \text { to } 10 \% \text { of fine sand are interbedded at } 430,450 \\
\text { and } 490 \mathrm{~cm} \text { deep }\end{array}$ \\
B & $\begin{array}{l}\text { Clay }<3 \% \text { Sand }>50 \% \text { This facies is characterised by two classes } \\
\text { adjusted on } 150-200 \mu \mathrm{m} \text { and } 400-800 \mu \mathrm{m} \text { (for example samples }\end{array}$ & $\begin{array}{l}\text { Three levels with } 1000-2000 \mu \mathrm{m} \text { fraction up to } 8 \% \text { correspond } \\
\text { to organic matter and peat facies. }\end{array}$ \\
N 270 and N 330; Fig. 6). & $\begin{array}{l}\text { The } 100-150 \mu \text { m class marks the transition between the } \\
\text { previous and following facies. }\end{array}$ \\
C & Clay: $7-14 \%$ Silt: $60-70 \%$ & $\begin{array}{l}\text { An organic layer at a depth of } 140 \mathrm{~cm} \text { well differentiated by a } \\
\text { particle size up to } 800 \text { mm. }\end{array}$ \\
D & $\begin{array}{l}\text { Clay }<3 \% \text { Sand }>50 \% \text { This facies is characterised by two classes } \\
\text { adjusted on } 150-200 \mu \mathrm{m} \text { and } 400-800 \mu \mathrm{m} .\end{array}$ & \\
\hline
\end{tabular}

increase of Vitis pollen. A riparian woodland (Alnus, Betula, Salix, Fraxinus and Carpinus) colonised the surroundings of the site $[25,63]$. The evidence of reforestation is marked by an increase of total pollen number/grams of sediment. The higher variations of the ratio are tied to the peaty deposits which mark a temporary break in the sedimentation. The development of Equisetum at the end of the phase B appears as a local phenomena in relation with the environmental hydromorphy.

A renewal of agricultural activities is recorded in phase C. It occurred between the end of the 3rd century and the beginning of the 5 th century AD (Table 1). This development seems to be continuous throughout the phase, until the early Middle Ages. Pollen of plants reflecting these agricultural activities (e.g. Cerealia, Secale, Cannabis) show higher rates. However the pollen association is slightly different from that of phase A, the absence of Vitis pollen marks the disappearance of the vineyard on the valley side. High rates of Alnus and $T$. angustifilia pollen indicate a wetter environment and they can partially mask the representation of other taxa. The analysis of charcoal content reveals a succession of several fire-events (C1-PCh, C2-PCh and $\mathrm{C} 3-\mathrm{PCh})$ associated to an increase in API. The diagram of charcoal influx clearly shows 3 peaks of cellulose-ligneous particles which are systematically followed by an abrupt decrease in tree pollen in the ratio AP/NAP (Arboreal Pollen content/Non Arboreal Pollen content). The three fire events appear also synchronous to the development of apophytes and to the higher values of Poaceae. They reflect the impact of burning and clearing in the surroundings of the site.

At the top of the sequence (phase D), Alnus pollen is dominant in the spectrum. The small decrease of API and charcoal curves in phase D could represent a slowing down of agricultural activities during the Early Middle Ages ([664 $(725,739,772) 887]$ cal AD; Table 1). The phase E shows a light increase of API correlated with a new peak in charcoal content.

\section{Discussion}

\subsection{Sediment sources and erosive process}

During phases B and D (Fig. 7), particle size allows the recognition of the common origin of the sandy fraction. This is supplied from deep layers of soils and substratum of the hill as displayed equally by the high carbonate content of sediments. The upper part of the valley side (F2) and the edge of the plateau (p-IVs/A) seem to be specially affected. The medium and lower parts of hill could have been protected by the forested vegetation cover. The increase in organic component and the development of peaty facies reveal a humidification of the environment with depositional phases alternating with phases of soil stabilisation. High variations of the pollen concentration agree with the model of successive alluviation, colluvial and soil forming processes. Well sorted sediments together with carbonate component give evidence that alluviation of the Doubs river is predominant in phases B-D. The carbonate fraction proceeds either directly from erosion processes of geological formations unaffected by pedogenesis or alluviation of the Doubs river with high content of silt and calcareous sand. Sediments were deposited during hydrologic events; floods are representative of a strong hydrodynamic system generating incisive erosion. The Plateau and the valley side are affected by gully erosion (Fig. 10).

During phases $\mathrm{A}$ and $\mathrm{C}$, the fine fraction is dominant; particle size reflects a transport of low energy favourable to loamy and clayey sediments. The regular sedimentation was interrupted by some more sandy deposits which proceeded from the bottom layer of the hill (p-IVs).

Magnetic susceptibility allows the interpretation of these results more accurately (Fig. 5). In the sedimentary accumulation, the increase in magnetic concentrations can be related to the sediment sources and erosive processes of soils $[15,17,54]$. Magnetic susceptibility 


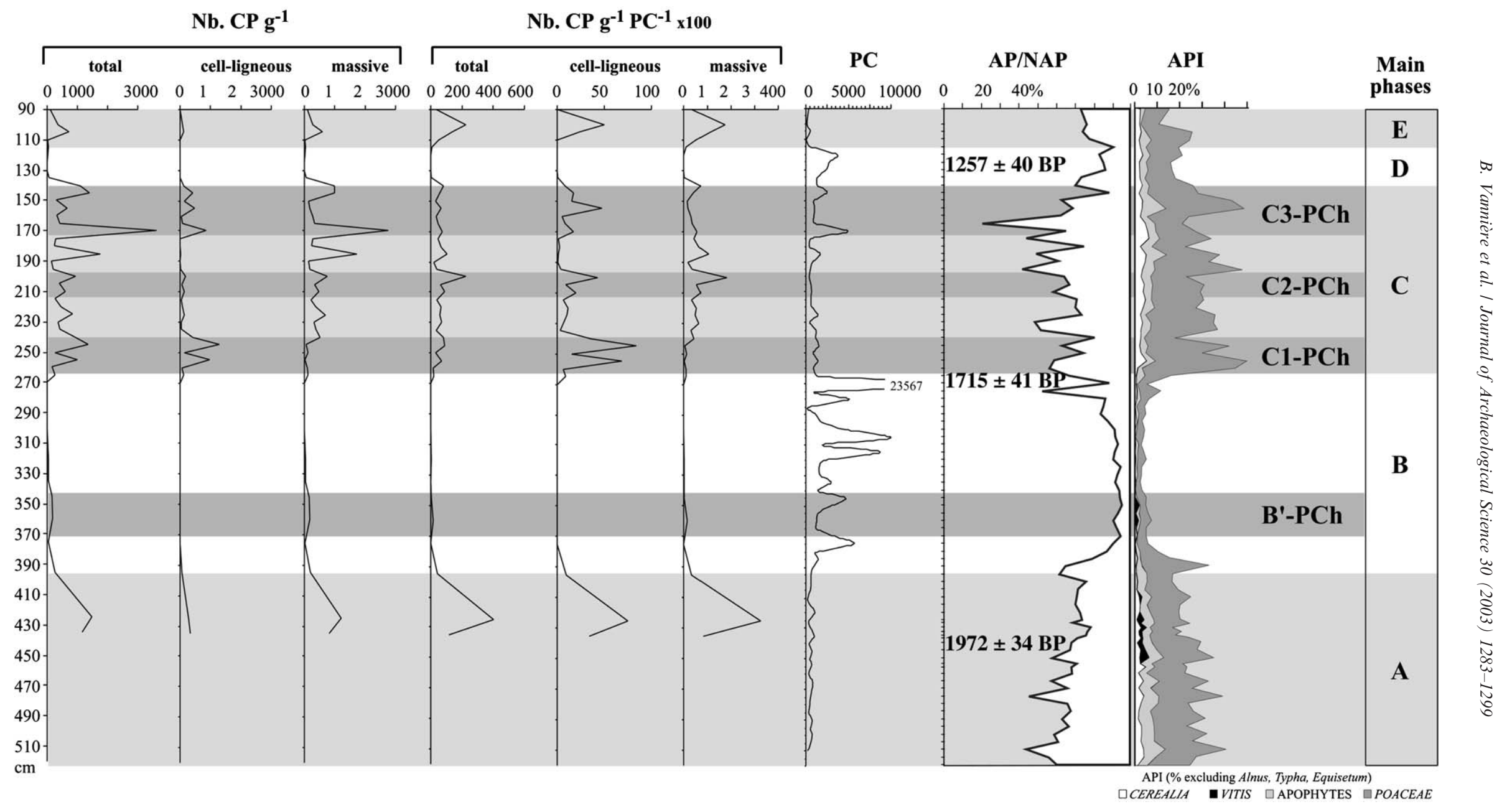

Fig. 8. Charcoal content diagram and simplified pollen diagram from the core $\mathrm{N}$ of Neublans. $\mathrm{Nb} . \mathrm{CPg}^{-1}: \mathrm{Number}$ of Charcoal Particles per gram of sediment; $\mathrm{Nb}$. CP $\mathrm{g}^{-1} \mathrm{PC}{ }^{-1}$ : Number of Charcoal Particles per gram of sediment expressed relative to Pollen Concentration; PC: Pollen Concentration (number of pollen per gram of sediment); AP/NAP: Arborean Pollen/Non Arborean Pollen. Main phases of the stratigraphic evolution (A to E) and local phases B'-Pch, C1-PCh, C2-PCh and C3-PCh. 


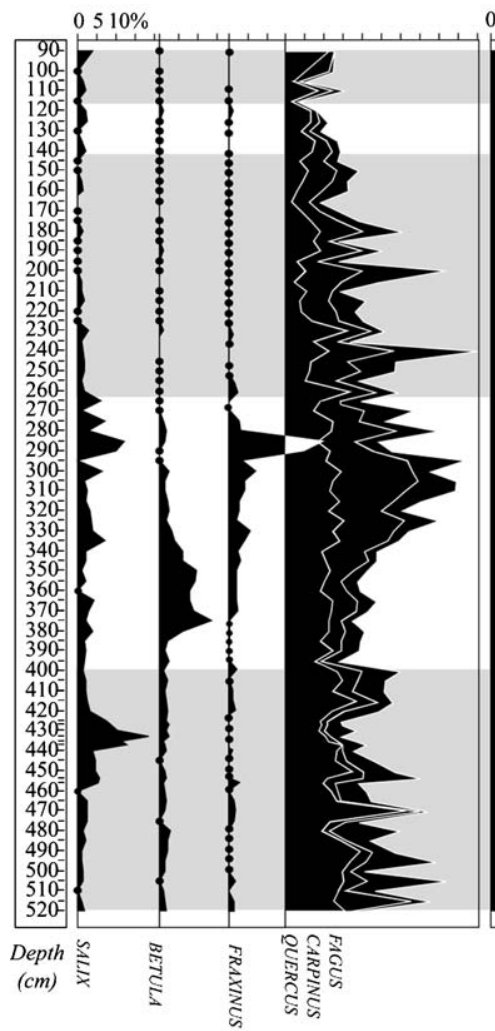

$\begin{array}{lllllllllll}0 & 10 & 20 & 30 & 40 & 50 & 60 & 70 & 80 & 90 & 100 \%\end{array}$

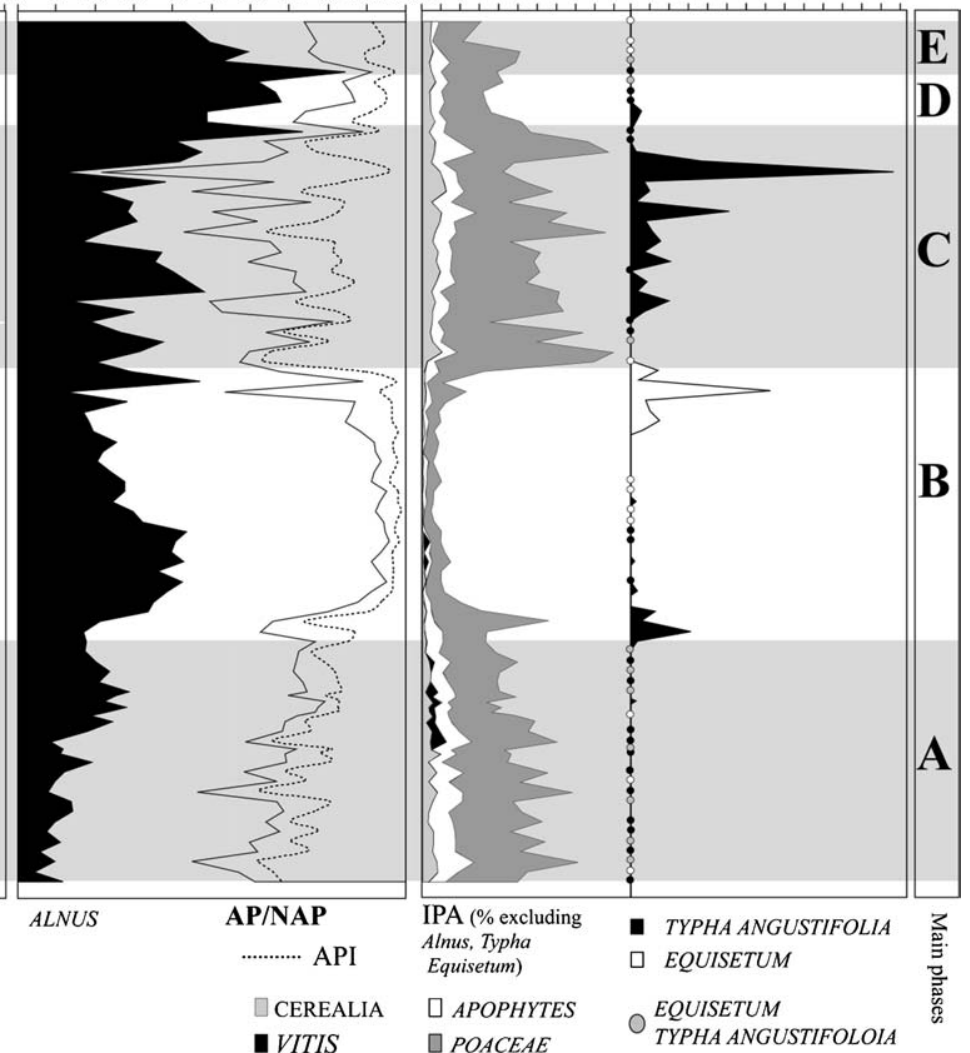

Fig. 9. Simplified pollen diagram from the core N of Neublans, $184 \mathrm{~m}$ asl (Jura, France)/

depends mainly on magnetite concentration in sediments. Nevertheless, in the case of low concentration of ferrimagnetic minerals (magnetite and maghaemite), the value of magnetic susceptibility can be largely influenced by diamagnetic minerals (quartz, carbonates) [60]. A dilution of magnetic signal can also be observed in organic sediments [66]. For core $\mathrm{N}$ of Neublans, the lower values of magnetic susceptibility correspond to peaty facies, organic loams and to a large extent, to carbonate silt (phases B and D). At the opposite, clayey facies are marked by high values of magnetic susceptibility (phases A and C). This observation is in accordance with the conclusions of Mullins [44] and Maher [39] about magnetic minerals of pedological origin which are preferentially linked to the clayey fraction. The increase of magnetic susceptibility in sediment records is often due to fire action on soil $[26,34,45,51,52]$. In the case of Neublans, the relation between soil erosive processes and increase in magnetic susceptibility is well established. However, simultaneous occurrence of charcoal influx, indicator of fires, and high values of magnetic susceptibility is not yet explained. For instance, in deposits of sub-phase $\mathrm{B}^{\prime}$-MS, the increase in magnetic susceptibility corresponds with any variation in charcoal particle influx. Dearing et al. [17] consider that the secondary formation of ferrimagnetic minerals (magnet-

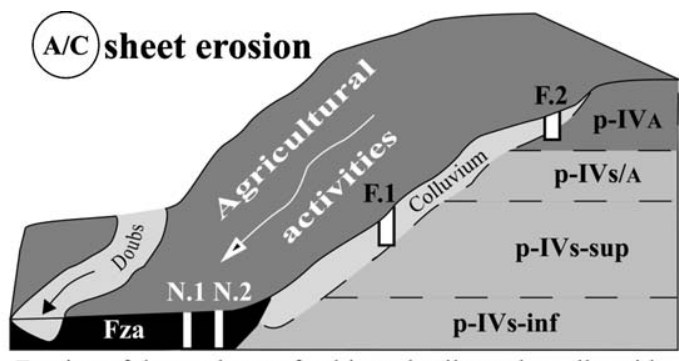

Erosion of the top layer of cultivated soils on the valley side. Silty loam deposits resulting from unconcentrated runoff.

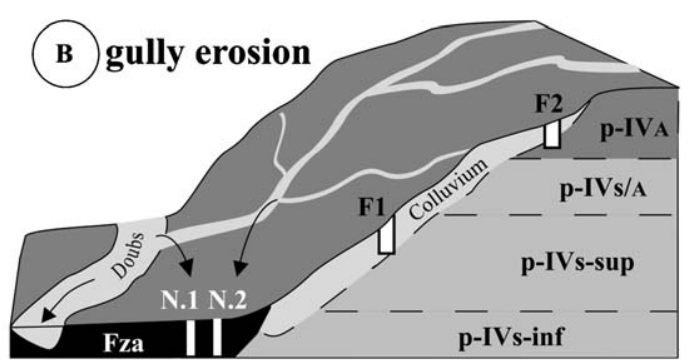

Erosion of the lower layers of soils and bebrock on the valley side. Sandy loam deposits resulting from flooding of Doubs river and reactivation of dry brooks occurred during the $3^{\text {rd }}$ century hydrological crisis.

Fig. 10. 3D modelling representation of erosion and depositional processes during the main phases (A, B, C; see also Figs. 5, 6 and 8) of the land-use history of Neublans site. 
ite and maghemite) resulting from a rise in temperature during fire appears as a minor mechanism or as a local phenomenon in comparison to oxidation-reduction and biochemical processes due to microbial activity in soils. Generally, susceptibility magnetic measurements are not closely linked to fire signals $[26,36,43]$. Therefore, the increase in magnetic susceptibility appears as a result of soil erosion arising from clearing and cultivation activities on the valley side $[15,29,32]$.

Soils were generally submitted to two types of degradation: the first one, which was slow and progressive, occurred under a permanent vegetation cover which modified pedogenesis, the second one, more rapid, which affected cultivated soils. Beginning with a degradation of soil structure, it emerges in most cases during erosion processes [18]. Deforestation not only changed the vegetation but also exposed the soils to the erosion forces of wind and water. Unprotected by a permanent vegetation cover, they were more exposed to sheet erosion $[18,58]$. Finer elements of phases $\mathrm{A}$ and $\mathrm{C}$ would proceed from soils uncovered after clearing of the valley side. In that way, the cultivation of vine on the valley side most certainly accelerated erosive processes of soils. The entrainment phases $\mathrm{A}$ and $\mathrm{C}$ results both from running off of fine elements of the upper layers of soils linked to agricultural activities (Fig. 10).

\subsection{Reconstruction of land-use history and hydrological changes}

The land-use history of the studied area can be summarised in five main phases: A, B, C, D, E (Figs. 5 and 8 \& Fig. 9).

During period $\mathrm{A}$, the landscape opened by clearing and burning, is assigned to pastures and cultivation, especially vineyard. Sheet erosion of soils due to agricultural activities on the valley side is recorded. The scheme of land management of the valley side can probably be generalised to the whole area. Archaeological maps of the valley and plateau (Fig. 3A and B) show numerous traces of human occupation since the Iron Age. On the plateau, the pollen diagram from the pool "l'étang Daufin", near Authumes site, proves that changes of vegetation cover resulting from human impact are recorded as far back as the first Iron Age, [844,546] cal $\mathrm{BC}$ [50]. The human impacts increased progressively to reach a maximum during the 1 st and 2 nd centuries AD [14].

The decrease of agricultural activities occurring during phase B, begins after the second half of the 2nd century AD. Pollen spectra record a high decrease of API and forest recolonisation (Fig. 9; [25]). Changes in drainage pattern and river flow are synchronous with successive flooding events recorded between AD 50/250 in neighbouring rivers such as the Saône and Rhône and in some other fluvial basins of Western Europe [7,4,65].
This renewal of hydrological activity reflects a major climatic deterioration of the Holocene period. It may coincide with a short but durable rise in lake levels occurring at 100/200 cal AD in the Jura Mountains, phase of "Petit Maclu 1" [37,38]. From an archaeological point of view, it is not possible to assert that the decrease in agricultural activities observed locally has a regional equivalent. The human occupation remains dense throughout the period despite chronological dubiousness about the antiquity of settlement. It is only in and after the 3rd century AD that the first signs of a human occupation controlled by climate and hydrologic constraint become discernible [2]. However, no significant evidence of a decrease in expansion was really recorded in the lower Doubs valley by archaeological documentation [14] and pollen analysis [25]. The riparian woodland, by filtering the pollen spectra, caused a dilution of anthropogenic signal in the core surroundings. Sedimentological analysis reveals preferentially some environmental changes induced by climate and its components such as hydrology and vegetation cover. However, the decrease of agricultural activities on the valley side seems to be effective. The absence of charcoal particles in the sediments and deforestation occurring in B phase agree with this interpretation. The historical abandonment of vine cultivation [14] and pedologic specificity of the valley side appear as a plausible explanation for the modification of agricultural development in the region during the 2 nd and $3 \mathrm{rd}$ centuries $\mathrm{AD}$, but it is necessary to study the history of farming on a large scale by including the whole geomorphological entity of the valley side.

Phase B'-MS (Fig. 5) attests a temporary break in sedimentation process, probably in inundation, and pedogenesis induced a rise in evapotranspiration rate synchronous with a drying phase of the environment [12]. The development of pedogenesis under forest cover may have favoured a mineral magnetic increase in soils [15]. This phase is characterised by the absence of API along with the expansion of deciduous woodland (Fig. 9). There is no impact of human activities on the landscape in the immediate surroundings of the site. The sequence of organic and peat layers interbedded with calcareous sandy loam reflects changes in the environmental conditions.

In phase $\mathrm{C}$, magnetic susceptibility values and pollen spectra, different from those of phase A, reflect a regional human impact on the environment. High values of Poaceae (20 to $30 \%$ ) and species found in pastures (e.g. P. major/media, P. lanceolata, Rumex) are dominant in the pollen spectra, evocative of an openlandscape. The high rates of Alnus and T. angustifolia partially mask the representation of the others species (Fig. 9). This pollen association and organic sediments reveal a wetter local environment. Evidence of deforestation, marked by the decline of arboreal pollen 
and high charcoal particle concentration, could be related to the expansion of agropastoral activities and to a new agricultural expansion beginning during the 3rd and 4th centuries AD. The valley side was regularly cultivated and farmed until the 8th century AD. During this period, peaks of charcoal suggest a recurrent use of fire for clearing or maintenance of the agricultural landscape. The fire signals give evidence of three phases of human impacts (sub-phases C1-PCh, C2-PCh and C3-PCh; Fig. 8). The various peaks of API curves indicate successive clearing and an extension of points farming. The timing of these particular events is actually unknown. New chronological reference, such as radiocarbon dates or archaeological data, would permit precision in the dynamics of land management. The continuous occurrence of large particles of charcoal during this phase is the result of plough soil erosion related to agricultural practices [62].

Phase $\mathrm{D}$, similar to the sedimentary phase $\mathrm{B}$, is dated to $[664,887]$ cal AD (Table 1). It marks a new climatic deterioration, contemporaneous with the transgressive phase of Petit Maclu 2, recorded at 650/750 AD in lake-level fluctuations in the Jura [37,38]. Evidence for of this climate deterioration is noted by Berger [4] in the Rhône valley is the 7 th and 8th centuries AD. During phase D, a recrudescence of Alnus gives clear evidence of a humidification of the environment but no significant decrease in agricultural activities is recorded by palynology.

\section{Conclusion}

The study of physical and biological characteristics of the sequences of Neublans allows us to define respectively the role of climate control and of human impacts in sedimentation. In the investigated area, the process of sedimentary accumulation was influenced by a strong local human impact on the environment; it expresses a more regional influence when the intensity and frequency of rainfall became the predominant factor. Then, the natural dynamics of the environmental evolutions appear as a constraining factor of human occupation.

Agricultural activities unquestionably represent a factor of soil erosion, but it is a specific type of erosion which affects fine elements. The clearing seems to favour surface run off and sheet erosion. Climatic deterioration may generate, by changing the water balance, erosion which can entrain more coarse materials. It is very likely that land management has amplified these phenomena, but only the joint impact of the two main factors affecting sedimentation, human activities and climate, could explain the occurrence of the more violent sedimentary crisis. Same climatic hypothesis is proposed by Groove [27] to explain fluvial deposits in Mediterranean context during the early Holocene. Micro-charcoal analysis and specially morphological particles differen- tiation appear as a relevant mean for the identification of specific stage in the land management during historic and prehistoric periods [64]. In the multi-proxy approach, fire signals provide original information's about temporality of human impact and type of practices.

\section{Acknowledgements}

The authors express their sincere thanks to J.-P. Simonnet and H. Richard for their help in field working, A. Buttler, M. Magny and the referees for their constructive review of the manuscript, and C. Bossuet for the improvement of the English version.

\section{References}

[1] C.K. Ballantyne, G. Whittington, Late Holocene floodplain incision and alluvial fan formation in the central Grampian Highlands, Scotland: chronology, environment and implications, Journal of Quaternary Science 14 (7) (1999) 651-671.

[2] P. Barral, G. Bossuet, C. Camerlynck, M. Dabas, A. Daubigney, Authumes le Tertre, Saône-et-Loire, Rapport d'activité scientifique, Prospections, Fouille programmée, Service Régional de l'Archéologie de Bourgogne, Dijon, 2000.

[3] K.E. Behre, The interpretation of anthropogenic indicators in pollen diagrams, Pollen et Spores 23 (1981) 223-245.

[4] J.F. Berger, Facteurs anthropiques et naturels de l'évolution des paysages romains et protomédiévaux du Bassin valdainais (Drôme), in: S. van der Leeuw (Ed.), L'homme et la dégradation de l'environnement, XVe Rencontres internationales d'Archéologie et d'Histoire d'Antibes, Actes des rencontres 20 21-22 Octobre 1994, APDCA, Sophia-Antipolis, 1995, pp. 79-115.

[5] B.E. Berglund, Vegetation and human influence in south scandinavia during prehistoric times, Oikos Supplement 12 (1969) 9-26.

[6] V. Bichet, M. Campy, J.F. Buonchristiani, C. Digiovanni, M. Meybeck, H. Richard, Variations in sediment yield from the upper Doubs river carbonate watershed (Jura, France) since Late-glacial period, Quaternary Research 51 (1999) 267-279.

[7] J.P. Bravard, A. Vérot, P.G. Salvador, Le climat d'après les informations fournies par les enregistrements sédimentaires fluviatiles étudiés sur les sites archéologiques, Les Nouvelles de l'Archéologie 50 (1992) 7-13.

[8] J.C. Brun-Cottan, Vertical transport of particles within the Ocean, in: R. Reide (Ed.), The Role of Air-Sea Exchange in Geochemical Cycling, NATO-ASI, Sophia-Antipolis, 1986, pp. 83-111.

[9] J.S. Clark, Stratigraphic charcoal analysis on petrographic thin sections: application to fire history in northwestern Minnesota, Quaternary Reseach 30 (1988) 81-91.

[10] J.S. Clark, T.C. Hussey, Estimating the mass flux of charcoal from sedimentary records: effects of particle size, morphology, and orientation, The Holocene 6 (2) (1996) 129-144.

[11] J.S. Clark, P.D. Royall, Particle-size evidence for source areas of charcoal accumulation in late Holocene sediments of Eastern North American lakes, Quaternary Research 43 (1995) 80-89.

[12] M.-A. Courty, Environnements géologiques dans le nord-ouest de l'Inde. Contraintes géodynamiques au peuplement humain protohistorique, Ph.D. Thesis, University of Bordeaux, 1990.

[13] A. Daubigney, P. Barral, G. Bossuet, E. Gauthier, Prospection thématique "Terroirs antiques du canton de Pierre-de-Bresse. 
Occupation du sol en Bresse Bourguignonne", Service Régional de l'Archéologie de Franche-Comté, Besançon, 1999.

[14] A. Daubigney, P. Barral, G. Bossuet, E. Gauthier, C. Petit, H. Richard, Anthropisation des zones humides: fenêtre sur le cas de la basse vallée du Doubs, in: Table ronde "Occupation et gestion des zones humides en Gaule durant l'Age du fer, l'Antiquité et le haut Moyen Age", in press

[15] E. de Jong, P.A. Nestor, D.J. Pennock, The use of magnetic susceptibility to measure long-term soil redistribution, Catena 32 (1998) 23-35.

[16] J. Dearing, Environmental Magnetic Susceptibility using the Bartington MS2 System, Chi Publishing, Kenilworth, England, 1999.

[17] J.A. Dearing, K.L. Hay, S.M.J. Baban, A.S. Huddleston, E.M.H. Wellington, P.J. Loveland, Magnetic susceptibility of soil: an evaluation of conflicting theories using a national data set, Geophys. J. Int. 127 (1996) 728-734.

[18] Ph. Duchaufour, Pédologie. Sol, végétation, environnement, Masson, Paris, 1995.

[19] J.P. Eberhart, Analyse structurale et chimique des matériaux, Dunod, Paris, 1989

[20] N. Fédoroff, M.-A. Courty, Le rôle des facteurs anthropiques et naturels dans la dynamique actuelle et passée des paysages méditerranéens - Cas du bassin de Vera, sud-est de l'Espagne, in: S. van der Leeuw (Ed.), L'homme et la dégradation de l'environnement, XVe Rencontres internationales d'Archéologie et d'Histoire d'Antibes, Actes des rencontres 20-21-22 Octobre 1994, APDCA, Sophia-Antipolis, 1995, pp. 115-141.

[21] N. Fédoroff, M.-A. Courty, M.-L. Thompson, Micromorphological evidence of paleoenvironmental changes in Pleistocene and Holocene paleosols, in: L.A. Douglas (Ed.), Soil Micromorphology, Elsevier Pub, Sophia-Antipolis, 1989, pp. 653-665.

[22] R. Fleury, Notice explicative de la feuille Pierre-de-Bresse à 1/50 000, B.R.G.M, Orléans, France, 1985.

[23] I.D.L. Foster, T.M. Mighall, C. Wotton, P.N. Owens, D.E. Walling, Evidence for mediaeval soil erosion in the South Hams region of Devon, UK, The Holocene 10 (2) (2000) 261-271.

[24] E. Gauthier, Mise en évidence pollinique de la culture de la vigne au I $^{\text {er }}$ siècle après J.-C. dans la plaine du Doubs (Neublans, Jura), Rev. d'Archéométrie 24 (2000) 63-69.

[25] E. Gauthier, Évolution de l'impact de l'homme sur la végétation du massif jurassien au cours des quatre derniers millénaires. Nouvelles données polliniques, Ph.D. Thesis, University of Franche-Comté, 2001.

[26] S.J. Gedye, R.T. Jones, W. Tinner, B. Ammann, F. Oldfield, The use of mineral magnetism in the reconstruction of fire history: a case study from Lago di Origlio, Swiss Alps, Palaeogeogr. Palaeoclimatol. Palaeoecol. 164 (1-4) (2000) 101-110.

[27] A.T. Groove, The "Little Ice Age" and its geomorphological consequences in Mediterranean Europe, Climatic Change 48 (2001) 121-136.

[28] S.R. Higgitt, F. Oldfield, P.G. Appleby, The record of land use change and soil erosion in the late Holocene sediments of the Petit Lac d'Annecy, eastern France, The Holocene 1 (1) (1991) 14-28.

[29] I. Hussain, K. Olson, R. Jones, Erosion patterns on cultivated and uncultivated hillslopes determined by soil fly ash contents, Soil Science 9 (1998) 726-738.

[30] M. Joly, E. Gauthier, Vignoble et viticulture dans le centre-est de la Gaulle au Ier siècle, in press.

[31] M. Jorda, M. Provensal, Impact de l'anthropisation et du climat sur le détritisme en France du sud-est (Alpes du sud et Provence), Bull. Soc. Géol. France 167 (1) (1996) 159-168.

[32] P. Lageras, P. Sandgren, The use of mineral analyses in identifying middle and late Holocene agriculture - a study of peat profiles in Smaland, Southern Sweden, Journal of Archaeological Science 21 (1994) 687-697.
[33] M. Latalowa, Man and vegetation in the pollen diagrams from Wolin island (NW Poland), Acta Palaebotanica 32 (1992) 123-249.

[34] E. Le Borgne, Influence du feu sur les propriétés magnétiques du sol et du granite, Annals of Geophysics 16 (1960) 159-195.

[35] S. Lesourd, Processus d'envasement d'un estuaire macrotidal: zoom temporel du siècle à l'heure; application à l'estuaire de la Seine, Ph.D. Thesis, University of Caen-Basse Normandie, 2000.

[36] C. Long, C. Whitlock, P. Bartlein, S. Millspaugh, A 9000-year fire history from the Oregon coast range, based on a high-resolution charcoal study, Canadian Journal of Forest Research 28 (1998) 774-787.

[37] M. Magny, Le climat à la fin de l'Age du Fer et dans l'Antiquité (500 BC-500 AD). Méthodes d'approche et résultats, Les Nouvelles de l'Archéologie 50 (1992) 32-36.

[38] M. Magny, Reconstruction of Holocene lake-level changes in the French Jura ; methods and results, in: F. Burkhard et al. (Eds.), Palaeohydrology as Reflected in Lake-level Changes as Climatic Evidence for Holocene times, Special Issue, ESF Project European Palaeoclimate and Man 17, 1998, pp. 67-85.

[39] B.A. Maher, Characterisation of soils by mineral magnetic measurements, Physics of Earth and Planetary Interiors 42 (1986) 76-92.

[40] R.H. Meade, Movement and storage of sediment in river system, in: A. Lerman, M. Meybeck (Eds.), Physical and Chemical Weathering in Geochemical Cycles, Kluwer Academic, Dordrecht, 1988, pp. 165-180.

[41] R.H. Meade, T.R. Yuzyk, T.J. Day, Movement and storage of sediment in rivers of United States of America, The Geology of North America, vol. 0-1, Surface Water Hydrology, Geological Society of America, Dordrecht, 1990, pp. 255-280.

[42] J.D Milliman, J.P.M. Syvitski, Geomorphic/tectonic control of sediment discharge to the ocean: the importance of small mountainous rivers, J. Geol. 100 (1992) 525-544.

[43] S.H. Millspaugh, C. Whitlock, P.J. Bartlein, Variations in fire frequency and climate over the past $17000 \mathrm{yr}$. in central Yellowstone National Park, Geology 28 (3) (2000) 211-214.

[44] C.E. Mullins, Magnetic susceptibility of the soil and it significance in soil science, a review, J. Soil Sci. 28 (1977) 223-246.

[45] F. Oldfield, History of particulate atmospheric pollution from magnetic measurements in dated Finnish peat profiles, Ambio 10 (4) (1981) 185-188.

[46] D.G. Passmore, M.G. Macklin, Provenance of fine grained alluvium and late Holocene land-use change in the Tyne basin, northern England, Geomorphology 9 (2) (1994) 127-142.

[47] C. Petit, Un bassin d'avant-pays de type pelliculaire: la Bresseau Plio-pléistocène, Ph.D. Thesis, University of Bourgogne, 1993.

[48] C. Petit, M. Campy, J. Chaline, J. Bonvalot, Major paleohydrographic changes in Alpin foreland during the PliocenePleistocene, Boreas 25 (1996) 131-143.

[49] M. Provensal, C. Morhange, Seuils climatiques et réponses morphogéniques en Basse Provence à l'Holocène. Colloque AFEQ, Echelles des variations chronoclimatiques quaternaires et réponses des environnements, Quaternaire 5 (3-4) (1994) 113-118.

[50] H. Richard, Analyses polliniques du remplissage de l'étang Daufin à Authumes (71), in: A. Daubigney et al. (Ed.), Prospection thématique. Terroirs antiques du canton de Pierre-de-Bresse. Occupation du sol en Bresse bourguignonne. Rapport d'activité scientifique, Service Régional de l'Archéologie de Bourgogne, Dijon, 1995.

[51] T.A. Rummery, The effects of fire on soils and sediment magnetism, Ph.D. Thesis, University of Liverpool, 1981.

[52] T.A. Rummery, J. Bloemendal, J. Dearing, F. Olfield, R. Thompson, The persistence of fire-induced magnetic oxides in soils and lake sediments, Annales de Géophysique 35 (1979) 103-107. 
[53] C. Sauty, Approche géoarchéologique de la basse vallée du Doubs, Memory of de Maîtrise, University of Franche-Comté, 1999.

[54] H. Stockhausen, B. Zolitschka, Environmental changes since 13,000 cal. BP reflected in magnetic and sedimentological properties of sediments from Lakes Holzmaar (Germany), Quaternary Science Reviews 18 (1999) 913-925.

[55] M. Stuiver, P.J. Reimer, Extended ${ }^{14} \mathrm{C}$ data base and revised Calib $3.0{ }^{14} \mathrm{C}$ age calibration program, Radiocarbon 35 (1) (1993) 215-230.

[56] M. Stuiver, P.J. Reimer, E. Bard, J.W. Beck, G.S. Burr, K.A. Hughen, B. Kromer, F.G. McCormac, J. Plicht, M. Spurk, INTCAL98 Radiocarbon age calibration $24,000-0$ cal BP, Radiocarbon 40 (3) (1998) 1041-1083.

[57] A.M. Swain, A history of fire and vegetation in northeastern Minnesota as recorded in lake sediments, Quaternary Research 3 (3) (1973) 383-396

[58] M.P. Taylor, J. Lewin, Non-synchronous response of adjacent floodplain systems to Holocene environmental change, Geomorphology 18 (3-4) (1997) 251-264.

[59] M.P. Taylor, M.G. Macklin, K. Hudson-Edwards, River sedimentation and fluvial response to Holocene environmental change in the Yorkshire Ouse Basin, northern England, The Holocene 10 (2) (2000) 201-212.

[60] R. Thompson, F. Oldfield, Environmental Magnetism, Allen \& Unwin, London, 1986.

[61] J.B. Thornes, The palaeo-ecology of erosion, in: J.M. Wagstaff (Ed.), Landscape and Culture. Geo-archaeological and Archaeological Perspectives, Blackwell, Oxford, 1987, pp. 37-55.
[62] B. Vannière, Feu, agro-pastoralisme et dynamiques environnementales en France durant l'Holocène. Analyse du signal incendie, approches sédimentologiques et étude de cas en Berry, Pyrénées et Franche-Comté, Ph.D. Thesis, Institute National Agronomique of Paris-Grignon, 2001.

[63] B. Vannière, G. Bossuet, E. Gauthier, Susceptibilé magnétique et indices polliniques, marqueurs de l'impact anthropique et de la dynamique fluviale dans la basse vallée du Doubs (Jura, France) entre le $1^{\text {er }}$ et le VIIIe siècles après J.-C. C.R, Acad. Sci. Paris 331 (2000) 203-210.

[64] B. Vannière, D. Galop, C. Rendu, B. Davasse, Feu et pratiques agro-pastorales dans les Pyrénées Orientales: le cas de la montagne d'Enveitg (Cerdagne, Pyrénées-Orientales, France), Sud-Ouest Européen 11 (2001) 29-42.

[65] A. Vérot-Bourrely, J. Argant, J.P. Bravard, L. Chaix, Le paléoenvironnement du site de Gorge du Loup (Lyon 9e): les signes matériels de la dégradation d'après l'étude interdisciplinaire du gisement, in: S. van der Leeuw (Ed.), L'homme et la dégradation de l'environnement, XVe Rencontres internationales d'Archéologie et d'Histoire d'Antibes, Actes des rencontres 20-21-22 Octobre 1994, APDCA, Sophia-Antipolis, 1995, pp. 43-79.

[66] M. Williams, Evidence for the dissolution of magnetite in recent Scottish peats, Quaternary Research 37 (1992) 171-182. 